\title{
Infertility issues in men with sickle cell disease
}

\begin{abstract}
Patients with sickle cell disease (SCD), especially males, face a key problem in the form of infertility. Apart from low serum testosterone, abnormalities involving accessory sex organs are also observed in these patients. Infertility is a known complication among males with SCD, and it comes about due to reasons such as impotence, relative primary gonadal failure, priapism, and delayed or impaired sexual development. Infertility manifests due to multiple causes, including primary gonadal failure (hypogonadism), erectile dysfunction (ED) as a result of priapism, sperm abnormalities, and delayed or impaired sexual development. The ejaculate volume, sperm density, sperm motility, and normal sperm morphology were significantly reduced in these patients as compared with normal patients. Most importantly, primary testicular failure is marked by low levels of testosterone and infertility results mainly from diseases or conditions that affect and destroy the testis. The low levels of testosterone lead to fertility reduction, which is aggravated by impotence, secondary to earlier priapism. Studies among mice have shown that increased doses of HU increase testicular germ cell apoptosis, decrease sperm count, induce testicular atrophy, increase abnormal sperm morphology, and decrease sperm motility. A multifactorial etiology is responsible for impaired male fertility and it includes sperm abnormalities, ED, hypogonadism, and effect of therapy on sperm function. This paper summarizes some clinical manifestations which play an important role in the development of infertility among men with SCD. The author suggests that prospective studies among males with SCD should be carried out using various end points to determine cellular and functional impairment in fertility.
\end{abstract}

Keywords: infertility, sickle cell disease, hydroxyurea
Volume 2 Issue 3 - 2017

\author{
Salma M AIDallal, ' Nasser MAIDallal' \\ 'Depatment of Hematology Laboratory Specialties, Amiri \\ Hospital, Kuwait \\ ${ }^{2}$ Depatment of General Surgeon, Farwaniya Hospital, Kuwait
}

Correspondence: Salma MAIDallal, Haematology Laboratory Specialist, Amiri Hospital, Kuwait, Tel +965-9098I 98I, Emaildr.s.aldallal@outlook.com

Received: April 05, 2017 | Published: May 22, 2017
Abbreviations: SCD, sickle cell disease; RBC, red blood cell; VOC, vaso-occlusive crisis; RES, reticuloendothelial system; HU, hydroxyurea; ED, erectile dysfunction; FSH, follicle-stimulating; hormone; LH, luteinizing hormone

\section{Introduction}

Sickle cell disease (SCD) is an autosomal recessive genetic disorder marked by defective hemoglobin $(\mathrm{Hb})$ synthesis, which leads to the production of abnormal sickle hemoglobin $(\mathrm{HbS})$. $\mathrm{HbS}$ results from a single amino acid substitution, i.e., valine for glutamic acid at position 6 , in the $\beta$ globin gene. The disease results when both $\beta$ globin genes are abnormal-either heterozygous (i.e., combined with other abnormal hemoglobin's such as hemoglobin $\mathrm{C}[\mathrm{HbSC}]$ or $\beta$ thalassaemia [HbS-thal], or homozygous [HbSS]). The combination of a sickle $\beta$ globin gene with a normal (HbAS) gene results in the sickle cell trait, with no resultant anemia.

Under low oxygen concentrations, red blood cells (RBCs) that contain abnormal form become deformed (sickle shaped) and rigid. This impedes their ability to pass through microcirculation, with frequent clotting and thrombosis. The consequence of the obstruction is the production of ischemia and infarction. Infarcts are common in several organs and they are responsible for most clinical manifestations. ${ }^{2,3}$

SCD has the potential to affect several organs and systems. Acute vaso-occlusive crisis (VOC) is the most common and earliest clinical manifestation, which generally appears at pediatric age. Although it is usually the brain, lungs, bones and spleen which are affected, VOC could occur in any organ. Furthermore, anemia results from the rapid removal of abnormal cells by the reticuloendothelial system (RES), which reduces red cell life span.,

SCD affects millions of people across the world, and it is particularly common among people whose ancestors hail from subSaharan Africa, Saudi Arabia, Spanish-speaking regions, India and the Mediterranean countries. ${ }^{6}$

Infertility is a major issue in patients diagnosed with $\mathrm{SCD}$, and as medical advances enhance the quality of life, the issue of reproduction is and will remain the main concern. The disorder includes an array of complications which are relatively common, but data are limited. Furthermore, hydroxyurea (HU) therapy, the only therapy that was approved by US FDA in the year 1999, which aids in the prevention of vaso-occlusive pain in SCD has shown to contribute to decreased fertility in men afflicted with the condition. ${ }^{7}$ This review summarizes some factors that cause infertility in males with SCD.

\section{Infertility in men with SCD}

Infertility issues in men with SCD have been studied on a more frequent basis than in women. Infertility manifests due to multiple causes, including primary gonadal failure (hypogonadism), erectile dysfunction (ED) as a result of priapism, sperm abnormalities, and delayed or impaired sexual development. ${ }^{8}$ The ejaculate volume, sperm density, sperm motility, and normal sperm morphology were significantly reduced in these patients as compared with normal patients. ${ }^{9}$ Most importantly, primary testicular failure is marked by low levels of testosterone and infertility results mainly from diseases or conditions that affect and destroy the testis. ${ }^{10}$ The low levels of testosterone lead to fertility reduction, which is aggravated by impotence, secondary to earlier priapism. ${ }^{11}$ 
Methods to treat hypogonadism are limited. Testosterone undecanoate injections ${ }^{12}$ and clomiphene ${ }^{13}$ have been utilized with variable results. Many patients treated with testosterone reported enhanced libido and decreased ED. Again, normal testosterone levels could not be sustained among many patients throughout the course of the (12 months) treatment. ${ }^{12}$

\section{Hypogonadism}

Hypogonadism, a condition linked with infertility, poor testosterone production, poor libido and erectile dysfunction, develops in up to $24 \%$ of men with SCD. ${ }^{14}$ Patients show sparse facial, axillary and pubic hair and small testicular size. Laboratory findings reveal low testosterone levels with variable levels of follicle-stimulating hormone (FSH) and luteinizing hormone (LH). ${ }^{15}$

The possible pathophysiologic mechanisms of hypogonadism are disruption in the hypothalamic-pituitary-gonadal axis, which leads to primary testicular failure, ${ }^{16,17}$ or secondary hypothalamic-pituitary dysfunction. ${ }^{14,15,18,19}$

\section{Sperm abnormalities}

Sperm abnormalities are common in male patients with SCD; the rates being as high as $91 \% .{ }^{20}$ Low sperm count, density, poor motility, and increased abnormal morphology are more commonly found in SCD subjects compared with normal subjects. ${ }^{21,22}$ Sperm abnormalities may be caused due to hypogonadism or testicular infarction, although abnormalities are reported even when FSH, LH, and testosterone are normal. ${ }^{23}$ Sperm abnormality is not inevitably linked to impaired fertility in these patients. ${ }^{22}$ Additional prospective studies are required to figure the clinical consequences of abnormal sperm analysis and its influence on the fertility of SCD patients.

\section{Erectile dysfunction (ED)}

With incidence rates in the range of $21 \%-35 \%$, it can be said that ED occurs commonly among men afflicted with SCD. ${ }^{24,25,26}$ The etiology of ED is unclear; however, it is believed to be caused by largely recurrent or prolonged priapism. The management of ED, which is caused due to priapism, by way of penile implants, depends on the amount of penile tissue fibrosis. Penile implants are effective, but multiple complications could arise with their use. ${ }^{27,28}$ Therapeutic schemes to limit the length of priapism events and avoid priapism recurrences should be used.

\section{Hydroxyurea (HU) and fertility in men with scd}

Studies have shown that some of fertility issues emerge due to chronic medical therapies which are used to prevent or manage SCDrelated morbidity. ${ }^{29}$ Recent progress in SCD treatment, particularly with regard to the use of hydroxyurea (HU), has significantly improved the prognosis of patients with the condition. ${ }^{30,31}$ But more attention has been drawn toward the adverse effects of $\mathrm{HU}$, with issues being raised about abnormal spermatogenesis and teratogenic effects.

The theoretical risk of HU influencing sperm development lies in the fact that the drug is an antimetabolite. HU is a ribonucleotide reeducates inhibitor which acts as a S-phase-specific cytotoxic agent that impairs DNA synthesis. ${ }^{29}$ Its effects are short lived and cease to exist once the drug is removed. Therefore, once-daily administration of the drug has brief and intermittent cytotoxic effects on dividing cells. ${ }^{32}$
Studies among mice have shown that increased doses of HU increase testicular germ cell apoptosis, decrease sperm count, induce testicular atrophy, increase abnormal sperm morphology, and decrease sperm motility. ${ }^{29}$ Sickle-cell-transgenic mice have hypogonadism at baseline. After treatment with $\mathrm{HU}$, the mice showed decreased testicular size and increased sperm abnormalities compared with normal mice. ${ }^{33}$

Sperm abnormalities, including azoospermia, oligozoospermia, increased morphologic abnormalities, and decreased motility, occur in men afflicted with SCD and receiving HU. ${ }^{20,34-36}$ Whether these abnormalities are related to $\mathrm{HU}$ is not clear, but researchers opine that the length of $\mathrm{HU}$ therapy might correlate with the degree of sperm abnormalities. ${ }^{34,35}$

Yet, more research is required pertaining to the influence of $\mathrm{HU}$ on sperm production and male fertility. Careful monitoring of sperm abnormalities throughout the course of the therapy, with serial sperm analysis every 6-12 months has been recommended. ${ }^{32}$

\section{Conclusion}

While medical advances improving quality of life and rate of survival, and reducing disease-related morbidity, reproductive matters should take precedence among patients with SCD. A multifactorial etiology is responsible for impaired male fertility and it includes sperm abnormalities, ED, hypogonadism, and effect of therapy on sperm function. Prospective studies among males with SCD should be carried out using various end points to determine cellular and functional impairment in fertility. In addition, research studies are required to gain increased understanding of the relationship between hypogonadism, ED, sperm abnormalities, and male fertility. This is essential to better conduct management and therapy and involves monitoring the entire life span of the SCD patient as well as his HU therapy.

\section{Acknowledgments}

The author is grateful to www.manuscriptedit.com for providing English language editing and proofreading services.

\section{Conflict of interest}

Author declares that there is no conflict of interest.

\section{References}

1. Ejindu VC,HineAL, MashayekhiM, etal. Musculoskeletal manifestations of sickle cell disease. Radiographics. 2007;27(4):1005-1021.

2. Rees DC, Williams TN, Gladwin MT. Sickle-cell disease. The Lancet 2010;376(9657):2018-2031

3. Mayo Clinic. Diseases and Conditions-Sickle cell anemia. 2016.

4. Rosado E, Paixao P, Schmitt W, et al. Sickle cell anaemia- a review of the imaging findings. 2014.

5. Platt OS, Brambilla DJ, Rosse WF, et al. Mortality in sickle cell disease- life expectancy and risk factors for early death. $N$ Engl J Med. 1994;330(23):1639-1644.

6. Serjeant GR. The natural history of sickle cell disease. Cold Spring Harb Perspect Med. 2013;3(10):a011783.

7. DeBaun MR. Hydroxyurea therapy contributes to infertility in adult men with sickle cell disease: a review. Expert Rev. Hematol. 2014;7(6):767-773. 
8. Olambiwonnu NO, Penny R, Frasier SD. Sexual maturation in subjects with sickle cell anaemia: studies of serum gonadotropin concentration, hight, weight and skeletal age. J Pediatr. 1975;87(3):459-464.

9. Agbaraji VO, Scott RB, Leto S, et al. Fertility studies in sickle cell disease: semen analysis in adult male patients. Int J Fertil. 1988;33(5):347-352.

10. Abdulwaheed OO, Abdulrasaq AA, Sulaiman AK, et al. The hormonal assessment of the infertile male in Ilorin, Nigeria. Afri J of Endocrinology and Metabolism. 2002;3:62-64.

11. Friedman G, Freeman R, Bookchin R. Testicular function in sickle cell disease. Fertil Steril. 1974;25(12):243-248.

12. Morrison BF, Reid M, Madden W, et al. Testosterone replacement therapy does not promote priapism in hypogonadal men with sickle cell disease: 12-month safety report. Andrology. 2013;1(4):576-582.

13. Landefeld CS, Schambelan M, Kaplan SL, et al. Clomipheneresponsive hypogonadism in sickle cell anemia. Ann Intern Med. 1983;99(4):480-483.

14. Taddesse A, Woldie IL, Khana P, et al. Hypogonadism in patients with sickle cell disease: central or peripheral? Acta Haematol. 2012;128(2):65-68.

15. Dada OA, Nduka EU. Endocrine function and haemoglobinopathies: realtion between the sickle cell gene and circulating plasma levels of testesterone, luteininsing hormone (LH) and follicle stimulating hormone (FSH) in adult males. Clin Chim Acta. 1980;105(2):269-273.

16. Osegbe DN, Akinyanju OO. Testicular dysfunction in men with sickle cell disease. Postgrad Med J. 1987;63(736):95-98.

17. Parshad O, Stevens MC, Preece MA, et al. The mechanism of low testosterone levels in homozygous sickle-cell disease. West Indian Med J. 1994;43(1):12-14.

18. Abbasi AA, Prasad AS, Ortega J, et al. Gonadal function abnormalities in sickle cell anemia: studies in adult male patients. Ann Intern Med. 1976;85(5):601-605.

19. El-Hazmi MA, Bahakim HM, al-Fawaz I. Endocrine functions in sickle cell anemia patients. J Trop Pediatr. 1992;38(6):307-313.

20. Berthaut I, Guignedoux G, Kirsch-Noir F, et al. Influence of sickle cell disease and treatment with hydroxyurea on sperm parameters and fertility of human males. Haematologica. 2008;93(7):988-993.

21. CR Nahoum, EA Fontes, FR Freire. Semen analysis in sickle cell disease. Andrologica. 1980;12(6):542-545.

22. Osegbe DN, Akinyanju O, Amaku EO. Fertility in males with sickle cell disease. Lancet. 1981;2(8241):275-276.
23. Friedman G, Freeman R, Bookchin R. Testicular function in sickle cell disease. Fertil Steril. 1974;25(12):1018-1021.

24. Adeyoju AB, Olujohungbe AB, Morris J, et al. Priapism is sickle-cell disease; incidence, risk factors and complications - an international multicentre study. BJU Int. 2002;90(9):898-902.

25. Emond AM, Holman R, Hayes RJ, et al. Priapism and impotence in homozygous sickle cell disease. Arch Intern Med. 1980;140(11):1434-1437.

26. Madu AJ, Ubesie A, Ocheni S, et al. Priapism in homozygous sickle cell patients: important clinical and laboratory associations. Med Princ Pract. 2014;23(3):259-263.

27. Bertram RA, Carson CC 3rd, Webster GD. Implantation of penile prostheses in patients impotent after priapism. Urology. 1985;26(4):325-327.

28. Douglas L, Fletcher H, Serjeant G. Penile prostheses in the management of impotence in sickle cell disease. Br J Urol. 1990;65(5):533-535.

29. Smith-Whitley K. Reproductive issues in sickle cell disease. Blood. 2014;124(24):3538-3543.

30. Charache S, Terrin ML, Moore RD, et al. Effect of hyroxyurea on the frequency of painful crises in sickle cell anemia. Investigators of the multicenter study of hyroxyurea in sickle cell anemia. $N$ Engl J Med. 1995;332(20):1317-1322.

31. SM Bakanay. Mortality in sickle cell patients on hydroxyurea therapy Blood. 2004;105(2):545-547.

32. Jones KM, Niaz MS, Brooks CM, et al. Adverse effects of a clinically relevent dose of hydroxyurea used for the treatment of sickle cell disease on male fertility endpoints. Int J Environ Res Public Health. 2009;6(3):1124-1144.

33. Grigg A. Effect of hydroxyurea on sperm count, motility and morphology in adult men with sickle cell or myeloproliferative disease. Intern Med J. 2007;37(3):190-192.

34. Lukusa AK, Vermylen C. Use of hydroxyurea from childhood to adult age in sickle cell disease: semen analysis. Haematologica. 2008;93(11):e67.

35. Lukusa AK1, Vermylen C, Vanabelle B, et al. Bone marrow transplantation or hydroxyurea for sickle cell anemia: long-term effects on semen variables and hormone profiles. Pediatr Hematol Oncol. 2009;26(4):186-194

36. National Toxicology program. NTP-CERHR monograph on the potential human reproductive and developmental effects of hydroxyurea. NTP CERHR MON. 2008;21:7-10. 